\title{
Characterization, evaluation of nutritional parameters of Radix isatidis protein and its antioxidant activity in D-galactose induced ageing mice
}

Ping Xiao ${ }^{1,2}$, Hongzhi Huang ${ }^{2}$, Xiang Li ${ }^{2 *}$, Jianwei Chen ${ }^{2}$ and Jin-ao Duan ${ }^{1^{*}}$

\begin{abstract}
Background: Radix isatidis (Isatis indigotica Fort.) is an ancient medicinal herb, which has been applied to the prevention and treatment of influenza virus since ancient times. In recent years, the antioxidant activity of Radix isatidis has been widely concerned by researchers. Our previous studies have shown that Radix isatidis protein (RIP) has good antioxidant activity in vitro. In this study, the composition of the protein was characterized and its antioxidant activity in vivo was evaluated.
\end{abstract}

Methods: The model of oxidative damage in mice was established by subcutaneous injection of D-galactose for 7 weeks. Commercially available kits were used to determine the content of protein and several oxidation indexes in different tissues of mice. The tissue samples were stained with hematoxylin and eosin (H\&E) and the pathological changes were observed by optical microscope. The molecular weight of RIP was analyzed by sodium dodecyl sulfate polyacrylamide gel electrophoresis (SDS-PAGE). The amino acid composition of RIP was determined by a non-derivative method developed by our research group.

Results: RIP significantly increased the activities of antioxidant enzymes such as SOD, CAT, GSH-Px and total antioxidant capability (TAOC) but decreased the MDA level in the serum, kidney and liver. H\&E stained sections of liver and kidney revealed D-galactose could cause serious injury and RIP could substantially attenuate the injury. The analysis of SDS-PAGE showed that four bands with molecular weights of $19.2 \mathrm{kDa}, 21.5 \mathrm{kDa}, 24.8 \mathrm{kDa}$ and 40.0 $\mathrm{kDa}$ were the main protein components of RIP.

Conclusions: The results suggested that RIP had excellent antioxidant activity, which could be explored as a health-care product to retard aging and a good source of protein nutrition for human consumption.

Keywords: Radix isatidis protein, Oxidative damage, Antioxidant activity, Protein composition, D-galactose

\footnotetext{
* Correspondence: lixiang_8182@163.com; dja@njucm.edu.cn

${ }^{2}$ College of Pharmacy, Nanjing University of Chinese Medicine, Nanjing 210023, China

'Jiangsu Collaborative Innovation Center of Chinese Medicinal Resources Industrialization, National and Local Collaborative Engineering Center of Chinese Medicinal Resources Industrialization and Formulae Innovative Medicine, Jiangsu Key Laboratory for High Technology Research of TCM Formulae, and State Administration of Traditional Chinese Medicine Key Laboratory of Chinese Medicinal Resources Recycling Utilization, Nanjing University of Chinese Medicine, Nanjing 210023, China
}

(c) The Author(s). 2019 Open Access This article is distributed under the terms of the Creative Commons Attribution 4.0 International License (http://creativecommons.org/licenses/by/4.0/) which permits unrestricted use, distribution, and reproduction in any medium, provided you give appropriate credit to the original author(s) and the source, provide a link to the Creative Commons license, and indicate if changes were made. The Creative Commons Public Domain Dedication waiver (http://creativecommons.org/publicdomain/zero/1.0/) applies to the data made available in this article, unless otherwise stated. 


\section{Background}

Radix isatidis is the dried root of Isatis indigotica Fort. in the Brassicaceae family. It is primarily distributed in Anhui, Hebei, Jiangsu and Gansu provinces of China. Compounds in Radix isatidis mainly include lignans, alkaloids, amino acids, nucleotides, proteins and polysaccharides [1, 2]. As a common Chinese medicine, Radix isatidis has been used in China for more than 2000 years with good clinical effect [3]. In addition to antiviral activity, the antioxidant activity of Radix isatidis is also concerned by researchers $[4,5]$.

Synthetic antioxidants such as bultylated hydroxyanisole (BHA), butylated hydroxytoluene (BHT) and propyl gallate (PG) have potential hepatotoxicity and carcinogenic effects $[6,7]$. These concerns have triggered great interest in the exploration and discovery of natural antioxidants as alternatives to the current practice [8]. Plant protein is an important bioactive substance in traditional Chinese medicine, most of which have antioxidant activity. Therefore, screening proteins with potent antioxidant activity has become a new trend in biology, medicine and food science. Antioxidant peptides could effectively eliminate excess reactive oxygen free radicals in the body and protect the normal structure and function of cells and mitochondria. They were commonly used in the prevention and treatment of free radicalinduced diseases and anti-aging. Generally, antioxidant peptides encoded in proteins are released after heat treatment and digestion to play an antioxidant role [9].

Our previous study found that the high polar part of Radix isatidis has good antioxidant activity [10]. Radix isatidis contains a lot of water-soluble protein, accounting for $6 \sim 10 \%$. We have identified some of antioxidant peptides from RIP using proteomics techniques (unpublished data). RIP is a kind of non-immune source protein, which can promote the division of thymus $\mathrm{T}$ lymphocyte, improve the immune ability of the body, and have a good therapeutic and preventive effect on influenza [11, 12]. Antioxidants improve health not only by increasing antioxidant activity but also by inducing the protective immune response [13]. Previous researches conducted in our laboratory indicated that the antioxidant activities of Radix isatidis protein hydrolysates were significantly enhanced after simulated gastrointestinal digestion in vitro [14]. However, to our knowledge, it has not yet been reported that RIP had antioxidant activity in vivo. Consequently, it was necessary to study the antioxidant activities in vivo to confirm whether RIP was a good antioxidant.

This study set out to investigate the composition and antioxidant activities of RIP. We reported in detail the antioxidant activities of RIP by using D-galactose induced aging mice as in vivo model. The protein constituents were analyzed by SDS-PAGE and amino acids content of RIP was determined. This study could serve as a reference for the comprehensive utilization of RIP which was previously considered as waste.

\section{Materials and methods \\ Reagents and materials}

Radix isatidis was collected from an officially certified standardized planting base in Tongling city of the Anhui province (China). The botanical origin was authenticated by Professor Jianwei Chen (Nanjing University of Chinese Medicine). A voucher specimen has been deposited in the Herbarium of Nanjing University of Chinese Medicine (voucher No. 120615).

Dialysis bags were purchased from Yuanye Biotechnology Co., Ltd. (Shanghai, China). BCA protein assay kits and antioxidant assay kits such as superoxide dismutase (SOD), catalase (CAT), glutathione peroxidase (GSH-Px), total antioxidant capability (T-AOC) and malondialdehyde (MDA) were purchased from Nanjing Jiancheng Bioengineering Institute (Nanjing, China). Vitamin C (VC) and other chemical reagents were bought from Sinopharm Chemical Reagent Co., Ltd. (Shanghai, China). All reagents meet the purity required by the experiment.

\section{Preparation of Radix isatidis protein}

The preparation method of RIP referred to the method we have reported [14]. A certain amount of Radix isatidis powder was added to 20 times $(\mathrm{m} / \mathrm{v})$ of $50 \mathrm{mM}$ Tris- $\mathrm{HCl}$ solution $(\mathrm{pH}=7.8)$ for full immersion, and ultrasonic extraction was conducted for $60 \mathrm{~min}$. Then the extracted suspension was centrifuged at $3000 \mathrm{~g}$ for $5 \mathrm{~min}$. The supernatant was collected and ammonium sulfate was slowly added to a concentration of $70 \%(\mathrm{~m} / \mathrm{v})$. The mixture was placed in a refrigerator at $4{ }^{\circ} \mathrm{C}$ overnight. After centrifugation at $3500 \mathrm{~g}$ for $10 \mathrm{~min}$ the protein precipitant was collected. The protein was re-dissolved with distilled water and then loaded into dialysis bags (molecular mass cut off, $1000 \mathrm{Da}$ ) to remove residual salt and small molecule compounds at $4{ }^{\circ} \mathrm{C}$. The dialyzed protein solution was dried by freeze-drying and stored in a refrigerator at $-80^{\circ} \mathrm{C}$ for subsequent experiments.

\section{Analysis of the Radix isatidis protein Sodium dodecyl sulfate polyacrylamide gel electrophoresis (SDS-PAGE) analysis}

The RIP sample was analyzed by SDS-PAGE with slight modifications of the method described by Prandi [15] The RIP sample solution $(1 \mathrm{mg} / \mathrm{ml})$ and buffer solution were mixed by equal volume. The buffer solution $(\mathrm{pH}$ 6.8) consisted of $1 \%$ SDS, $0.005 \%$ bromophenol blue, $12.5 \%$ glycerol and 2.5\% 2-mercaptoethanol. Then the mixed solution was placed in a $95^{\circ} \mathrm{C}$ water bath for 5 min. After cooling down, prepared samples were 
separated by precast $12 \%$ gel on a Mini Protean II Dual Slab Cell (BIO-RAD) device. The separated gel was stained by Coomassie Brilliant blue method.

\section{Amino acid analysis}

The RIP sample (5 mg) was hydrolyzed in a sealed tube with $5 \mathrm{ml} 6 \mathrm{mM} \mathrm{HCl}$ at $110{ }^{\circ} \mathrm{C}$ for $24 \mathrm{~h}$. Alkaline hydrolysis was used to determine the tryptophan content. The hydrolyzed sample was centrifuged at $12000 \mathrm{~g}$ for $10 \mathrm{~min}$ and the supernatant was passed through a $0.22 \mu \mathrm{m}$ microporous membrane for subsequent analysis. Amino acid composition of RIP was analyzed using the method we developed previously [16].

\section{Evaluation of nutritional parameters}

The nutritional value of RIP was evaluated by the following formulas [17].

(a) The proportion of essential amino acids (E) to total amino acids $(\mathrm{T})$ of the protein:

(b) Amino acid score:

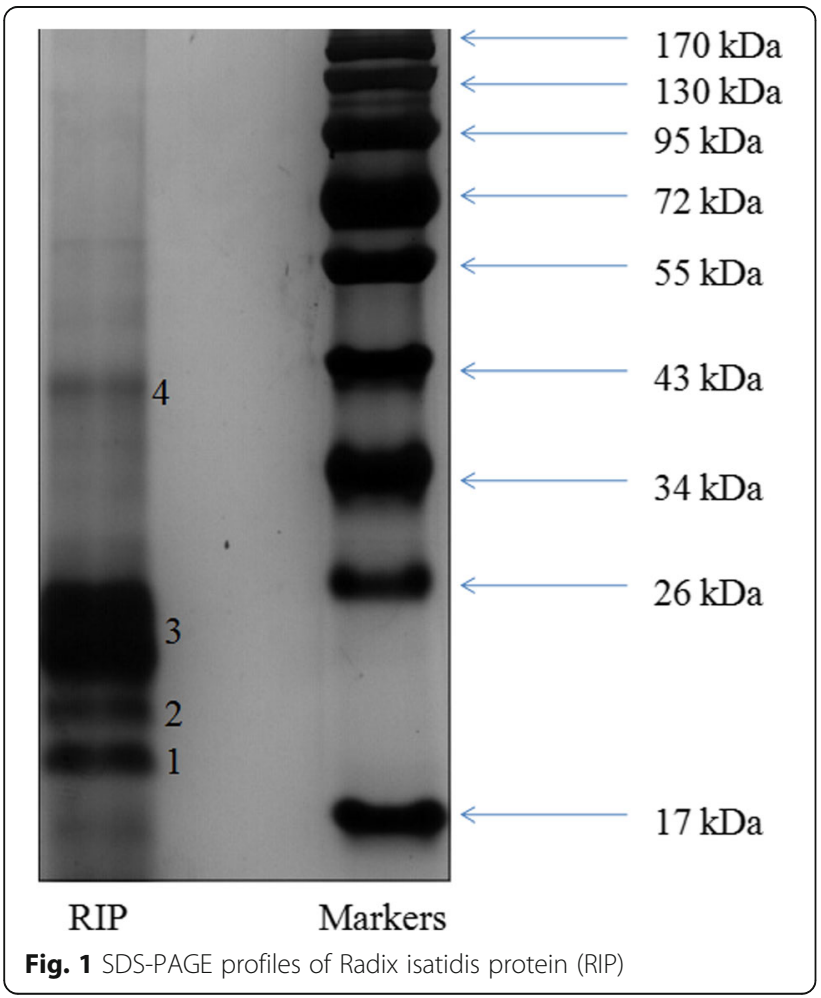

$$
=\left(\frac{\mathrm{mg} \text { of amino per } \mathrm{g} \text { test protein }}{\mathrm{mg} \text { of amino acid per g of FAO/WHO standard pattern }}\right) \times 100
$$

\section{Determination of the antioxidant activity of RIP in vivo}

Animal selection and experimental design

ICR male outbred mice (8-weeks-old) weighing $20.0 \pm$ $2.0 \mathrm{~g}$ were purchased from the Jiangsu University of Laboratory Animal Research Center. These mice were randomly divided into six groups with 10 mice in each group after 7-day adaptation period. Mice in the normal control group were given physiological saline solution $(0.9 \% \mathrm{NaCl}, \mathrm{w} / \mathrm{v})(10 \mathrm{ml} / \mathrm{kg} \mathrm{bw})$ per day by subcutaneous injection and gastric gavage. Mice in

Table 1 Amino acid composition of RIP and the FAO/WHO suggested requirements ( $2-5$ years old) for the essential amino acids ( $\mathrm{g} / 100 \mathrm{~g}$ of protein)

\begin{tabular}{|c|c|c|}
\hline Amino acids & RIP & $\begin{array}{l}\text { FAO/WHO suggested } \\
\text { requirements } \\
(2-5 \text { years old })\end{array}$ \\
\hline Isoleucine & $7.36 \pm 0.51$ & 2.8 \\
\hline Leucine & $3.92 \pm 0.24$ & 6.6 \\
\hline Lysine & $0.46 \pm 0.06$ & 5.8 \\
\hline Cysteine & $0.01 \pm 0.00$ & \\
\hline Methionine & $0.11 \pm 0.02$ & \\
\hline Total sulphur amino acids & 0.12 & 2.5 \\
\hline Tyrosine & $0.85 \pm 0.06$ & \\
\hline Phenylalanine & $4.08 \pm 0.19$ & \\
\hline Total aromatic amino acids & 4.93 & 6.3 \\
\hline Threonine & $5.06 \pm 0.83$ & 3.4 \\
\hline Tryptophan & $2.57 \pm 0.44$ & 1.1 \\
\hline Valine & $7.62 \pm 0.08$ & 3.5 \\
\hline Histidine & $1.74 \pm 0.04$ & 1.9 \\
\hline Total essential amino acids & 33.79 & 32.8 \\
\hline Arginine & $2.95 \pm 0.24$ & \\
\hline Aspartic acid + asparagine & $9.78 \pm 0.65$ & \\
\hline Glutamic acid + glutamine & $6.03 \pm 0.42$ & \\
\hline Serine & $2.36 \pm 0.04$ & \\
\hline Proline & $8.88 \pm 0.49$ & \\
\hline Glycine & $6.03 \pm 0.70$ & \\
\hline Alanine & $2.43 \pm 0.21$ & \\
\hline Total non-essential amino acids & 38.46 & \\
\hline${ }^{\mathrm{a}} \mathrm{E} / \mathrm{T}, \%$ & 46.77 & \\
\hline Amino acid score & 101.33 & \\
\hline${ }^{\mathrm{b}}$ Antioxidant amino acids & 29.63 & \\
\hline
\end{tabular}

${ }^{a}$ The proportion of essential amino acids to the total amino acids ${ }^{b}$ Antioxidant amino acids, it contains hydrophobic amino acids (valine, alanine, proline and leucine), aromatic amino acids (tyrosine, histidine, and phenylanine), and methionine [19] 
Table 2 Effects of increasing age and different treatments on the body weights (g) of ICR mice

\begin{tabular}{|c|c|c|c|c|c|c|c|c|}
\hline \multirow[t]{2}{*}{ Group } & \multicolumn{8}{|l|}{ Week } \\
\hline & 0 & 1 & 2 & 3 & 4 & 5 & 6 & 7 \\
\hline Normal control & $21.26 \pm 1.18$ & $26.60 \pm 1.57$ & $29.50 \pm 1.02$ & $32.32 \pm 1.30$ & $36.33 \pm 1.25$ & $38.34 \pm 1.57$ & $40.08 \pm 1.60$ & $42.77 \pm 1.15$ \\
\hline Model control & $21.49 \pm 1.24$ & $26.59 \pm 2.62$ & $29.74 \pm 1.28$ & $32.40 \pm 1.14$ & $36.51 \pm 1.32$ & $35.68 \pm 1.65^{d}$ & $35.04 \pm 0.92^{d}$ & $34.19 \pm 1.16^{d}$ \\
\hline Positive control & $21.38 \pm 1.05$ & $26.77 \pm 1.11$ & $28.41 \pm 1.67$ & $32.33 \pm 2.23$ & $35.99 \pm 2.62$ & $36.54 \pm 1.59^{a c}$ & $39.02 \pm 2.39^{b}$ & $41.59 \pm 2.92^{b}$ \\
\hline RIP (25 mg/kg) & $21.26 \pm 0.75$ & $26.08 \pm 1.43$ & $27.67 \pm 1.24^{\mathrm{ac}}$ & $31.08 \pm 1.57$ & $33.86 \pm 2.47^{\mathrm{ac}}$ & $36.14 \pm 2.42^{\mathrm{ac}}$ & $38.00 \pm 2.84^{b c}$ & $40.65 \pm 1.25^{b}$ \\
\hline RIP (50 mg/kg) & $21.56 \pm 0.69$ & $26.26 \pm 0.85$ & $30.85 \pm 1.27$ & $32.18 \pm 0.84$ & $35.54 \pm 2.38$ & $37.83 \pm 2.89^{c}$ & $38.63 \pm 3.06^{b c}$ & $40.12 \pm 3.01^{b}$ \\
\hline RIP(100 mg/kg) & $21.12 \pm 1.43$ & $26.82 \pm 1.09$ & $31.16 \pm 1.24$ & $33.73 \pm 1.91$ & $36.79 \pm 1.57$ & $37.81 \pm 2.47^{c}$ & $38.27 \pm 2.98^{b c}$ & $41.12 \pm 2.16^{\mathrm{b}}$ \\
\hline
\end{tabular}

Results are given as mean body weights \pm standard deviation (S.D.) $(n=10)$ and evaluated by one-way ANOVA followed by the Duncan's multiple-range tests.

Differences were considered to be statistically significant if $P<0.05$

a $P<0.05$, compared with model group

${ }^{\mathrm{b}} P<0.01$, compared with model group

c $P<0.05$, compared with normal group

d $P<0.01$, compared with normal group

the model control group were injected subcutaneously with D-galactose $(800 \mathrm{mg} / \mathrm{kg} \mathrm{bw})$ and given $0.9 \% \mathrm{NaCl}$ $(10 \mathrm{ml} / \mathrm{kg} \mathrm{bw})$ by gastric gavage each day. The Dgalactose was dissolved in physiological saline solution $(0.9 \%, \mathrm{w} / \mathrm{v})$ at a concentration of $80 \mathrm{mg} / \mathrm{ml}$. The volume of hypodermic injection was $0.1 \mathrm{ml} / 10 \mathrm{~g}$ bw. Mice in the positive control group were treated with VC (100 mg/ kg bw) dissolved in physiological saline by gastric gavage and $\mathrm{D}$-galactose $(800 \mathrm{mg} / \mathrm{kg}$ bw) by subcutaneous injection per day. Mice in the low dose, medium dose and high dose group were fed with RIP at doses of 25,50 and $100 \mathrm{mg} / \mathrm{kg}$ bw respectively by gastric gavage and subcutaneously injected with $\mathrm{D}$ galactose $(800 \mathrm{mg} / \mathrm{kg}$ bw) per day. The whole experiment lasted for 7 weeks, and the weight of mice on the first day and every week was recorded.

Sample preparation of serum, kidney, liver and brain tissue After the last drug administration, the mice were fasted for one night and then humanely sacrificed by cervical dislocation. Blood samples of mice were collected immediately from retrobulbar venous plexus and kept at $37^{\circ} \mathrm{C}$ for $1 \mathrm{~h}$. Then blood samples were centrifuged at $4000 \mathrm{~g}$ for $10 \mathrm{~min}$ at $4{ }^{\circ} \mathrm{C}$, and the supernatant was collected as serum for assays. Different tissues were excised and weighed immediately, then homogenized with ice-cold normal saline $(0.9 \%)(0.1 \mathrm{~g}$ tissue $/ \mathrm{ml}$ solution). The $10 \%$ homogenate was centrifuged at $4000 \mathrm{~g}$ for $20 \mathrm{~min}$ at $4{ }^{\circ} \mathrm{C}$ and the supernatant was used for further biochemical analysis.

\section{Histological analysis}

The liver and kidney tissues were fixed with fresh solution of $4 \%$ paraformaldehyde ( $\mathrm{pH} 7.4)$ which were prepared for histological analysis. All tissue sections were stained with hematoxylin and eosin (H\&E) and viewed under a light microscopy (Axioskop 40, Zeiss, Germany). Pathology reports were issued by a board certified veterinary pathologist who knew nothing about the grouping of our experiment.

\section{Analysis of kidney, liver, thymus and spleen indices} Different tissues of the mice were thoroughly separated and weighed to calculate the organ index. The organ index was calculated according to the following formula:

Table 3 Effects of different treatments on the liver, kidney, thymus and spleen indices in aging mice

\begin{tabular}{|c|c|c|c|c|c|c|}
\hline \multirow{2}{*}{$\begin{array}{l}\text { Index } \\
\text { (mg/ } \\
g \cdot b w)\end{array}$} & \multicolumn{6}{|l|}{ Group } \\
\hline & Normal control & Model control & Positive control & $\begin{array}{l}\text { RIP } \\
(25 \mathrm{mg} / \mathrm{kg})\end{array}$ & $\begin{array}{l}\text { RIP } \\
(50 \mathrm{mg} / \mathrm{kg})\end{array}$ & $\begin{array}{l}\text { RIP } \\
(100 \mathrm{mg} / \mathrm{kg})\end{array}$ \\
\hline liver & $42.27 \pm 2.72$ & $37.93 \pm 3.49^{d}$ & $40.43 \pm 2.03^{\mathrm{ac}}$ & $38.59 \pm 3.14^{\mathrm{ac}}$ & $40.54 \pm 3.40^{b c}$ & $40.72 \pm 2.48^{b c}$ \\
\hline kidney & $15.59 \pm 1.46$ & $13.74 \pm 1.69^{d}$ & $14.04 \pm 1.41^{\mathrm{ac}}$ & $13.97 \pm 1.20^{c}$ & $14.39 \pm 1.88^{a c}$ & $14.76 \pm 1.49^{\mathrm{ac}}$ \\
\hline spleen & $2.45 \pm 1.30$ & $2.17 \pm 0.50^{c}$ & $2.25 \pm 0.75^{a}$ & $2.29 \pm 0.67^{\mathrm{ac}}$ & $2.30 \pm 1.01^{\mathrm{ac}}$ & $2.37 \pm 0.58^{a}$ \\
\hline thymus & $2.48 \pm 0.64$ & $2.02 \pm 0.87^{c}$ & $2.32 \pm 0.50^{a}$ & $2.28 \pm 0.34^{\mathrm{ac}}$ & $2.35 \pm 0.50^{a}$ & $2.36 \pm 0.34^{a}$ \\
\hline
\end{tabular}

Data were presented as means \pm S.D. $(n=10)$ and evaluated by one-way ANOVA followed by the Duncan's multiple-range tests

a $P<0.05$, compared with model group

${ }^{b} P<0.01$, compared with model group

c $P<0.05$, compared with normal group

${ }^{\mathrm{d}} P<0.01$, compared with normal group 

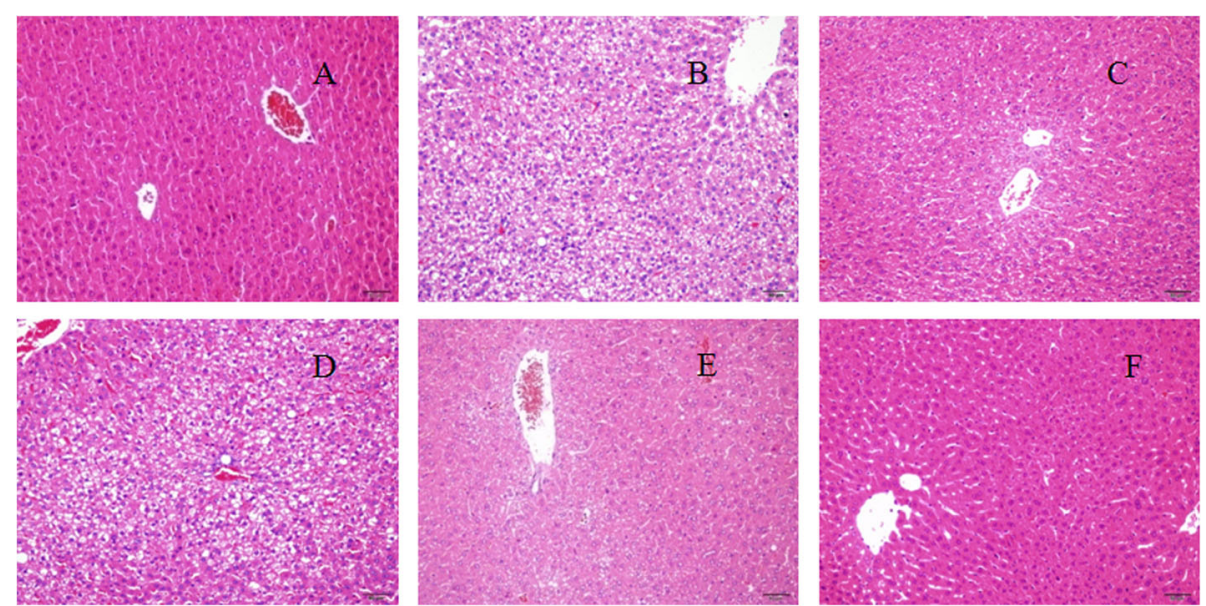

Fig. 2 Histopathological observation of liver in aging mice. Magnification, $\times 200$ : a normal control group; (b) model control group; (c) positive control group; (d) RIP of low dose group; (e) RIP of medium dose group; (f) RIP of high dose group

Index $=($ weight of organ/body weight $) \times 1000$

\section{Biochemical analysis}

Protein content, activities of catalase (CAT), superoxide dismutase (SOD) and glutathione peroxidase (GSH-Px) and the level of malondialdehyde (MDA) in tissue homogenates and serum samples were tested with commercial kits according to relevant operation instructions.

\section{Statistical analysis}

Data were presented as means \pm standard deviation (SD) and sample size is at least 3 in each group. Statistical significance was determined by one-way analysis of variance (ANOVA) followed by Duncan's multiple range test at a $5 \%$ level. If $P<0.05$, there was significant difference between the two groups.

\section{Results}

\section{SDS-PAGE analysis}

The results of SDS-PAGE were shown in Fig. 1. The molecular weight of RIP was calculated by comparison with standard protein markers. Two bands with molecular weights of $19.2 \mathrm{kDa}$ (1) and $21.5 \mathrm{kDa}$ (2) appeared in the lower portion of the gel. One weak band (4) with an approximate molecular weight of $40.0 \mathrm{kDa}$ was also observed. A band with a molecular weight of $24.8 \mathrm{kDa}$ (3) appeared as the largest band on the gel indicating that it was the most abundant protein in RIP.
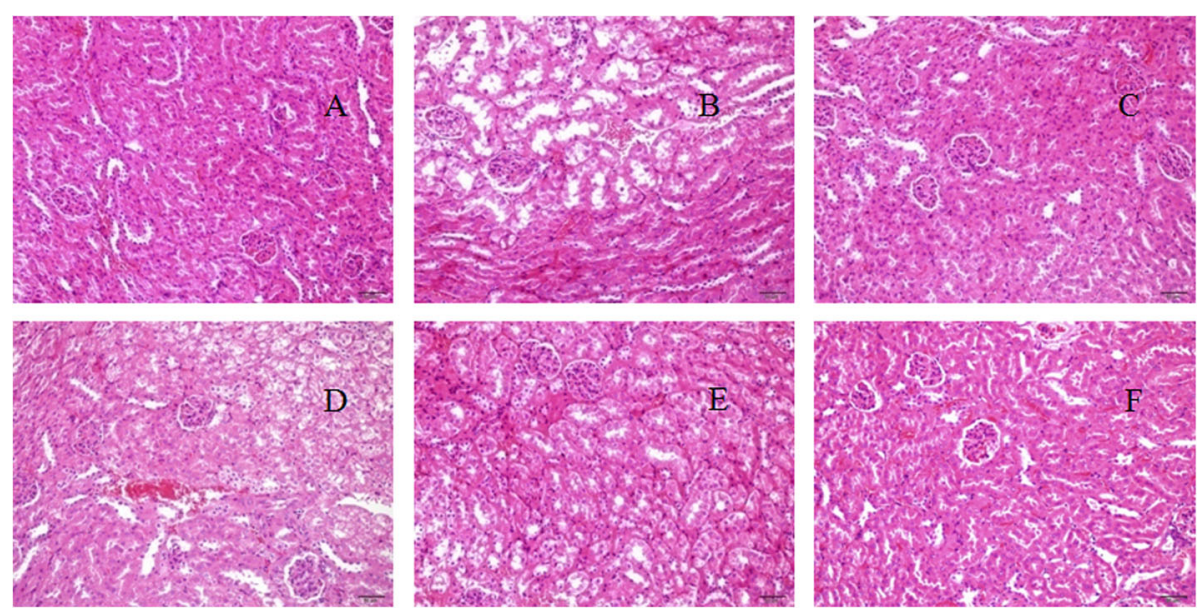

Fig. 3 Histopathological observation of kidney in aging mice. Magnification, $\times 200$ : a normal control group; (b) model control group; (c) positive control group; (d) RIP of low dose group; (e) RIP of medium dose group; (f) RIP of high dose group 
Table 4 Effects of different treatments on the activities of CAT (U/ml), SOD(U/ml), GSH-Px (U/ml) and levels of MDA (nmol/ml) and $\mathrm{TAOC}(\mathrm{U} / \mathrm{ml})$ in the serum of aging mice

\begin{tabular}{llllll}
\hline Group & MDA & TAOC & CAT & SOD & GSH-Px \\
\hline Normal control & $16.93 \pm 0.63$ & $8.09 \pm 0.42$ & $29.01 \pm 1.79$ & $208.63 \pm 27.29$ & $1094.56 \pm 69.89$ \\
Model control & $24.87 \pm 0.89^{\mathrm{d}}$ & $6.52 \pm 0.48^{\mathrm{d}}$ & $14.00 \pm 1.74^{\mathrm{d}}$ & $157.25 \pm 34.62^{\mathrm{d}}$ & $784.50 \pm 44.70^{\mathrm{d}}$ \\
Positive control & $19.77 \pm 0.58^{\mathrm{ad}}$ & $8.24 \pm 0.62^{\mathrm{b}}$ & $27.78 \pm 1.53^{\mathrm{b}}$ & $207.49 \pm 32.40^{\mathrm{b}}$ & $1069.13 \pm 24.48^{\mathrm{b}}$ \\
RIP $(25 \mathrm{mg} / \mathrm{kg})$ & $24.58 \pm 0.39^{\mathrm{d}}$ & $7.15 \pm 0.63^{\mathrm{c}}$ & $16.32 \pm 2.33^{\mathrm{ad}}$ & $165.53 \pm 18.84^{\mathrm{ad}}$ & $874.43 \pm 31.82^{\mathrm{ad}}$ \\
RIP $(50 \mathrm{mg} / \mathrm{kg})$ & $23.32 \pm 0.52^{\mathrm{ad}}$ & $7.65 \pm 0.35^{\mathrm{a}}$ & $24.83 \pm 2.13^{\mathrm{bc}}$ & $187.74 \pm 13.60^{\mathrm{bd}}$ & $950.97 \pm 19.70^{\mathrm{bc}}$ \\
RIP $(100 \mathrm{mg} / \mathrm{kg})$ & $20.99 \pm 0.62^{\mathrm{bd}}$ & $8.58 \pm 0.53^{\mathrm{b}}$ & $26.49 \pm 1.33^{\mathrm{bc}}$ & $227.47 \pm 16.31^{\mathrm{bc}}$ & $1167.18 \pm 82.58^{\mathrm{b}}$ \\
\hline
\end{tabular}

Data were presented as means \pm S.D. $(n=10)$ and evaluated by one-way ANOVA followed by the Duncan's multiple-range tests

a $P<0.05$, compared with model group

${ }^{\mathrm{b}} P<0.01$, compared with model group

c $P<0.05$, compared with normal group

d $P<0.01$, compared with normal group

\section{The amino acids composition of RIP}

The results of amino acid content of RIP were presented in Table 1. RIP contained a high amount of aspartic acid (9.78 g/100 g of RIP), followed by proline, isoleucine, glutamic acid, glycine, threonine in decreasing amounts. The total values of aromatic amino acids and essential amino acids content met the requirements set by FAO/ WHO [18]. The individual content for each of the essential amino acids (isoleucine, threonine, tryptophan and valine) also reached the minimum FAO requirements. The proportion of essential amino acids to the total amino acids (E/T) for RIP was $46.77 \%$ and the amino acid score was 101.33, suggesting that the RIP may have good nutritional value.

\section{Body weight}

At the beginning of the experiment, there were no remarkable difference among the mean body weight of the ICR mice in all groups $(P>0.05)$ (Table 2$)$. The mean body weight of the mice in all the groups, except the model control group, increased for the duration of the experiment. During the 7 weeks of the experiment, the mean body weight of animals in the model control group was significantly lower than the normal control group and the other treatment groups $(P<0.05)$. However, there were no significant differences between the normal control group and other treatment groups.

\section{The effect of the RIP on kidney, liver, thymus and spleen} indexes in aging mice

As shown in Table 3, the kidney, liver, thymus and spleen indexes in the model control group were significantly lower than the normal control group and other treatment groups $(P<0.05)$. Administration of RIP and VC seemed to have remarkable effects on increasing the indexes of the four organs in a dosedependent manner.

\section{Histopathological observation \\ The effect of RIP on histological changes in livers}

Histologic examinations of liver sections of aging mice treated with VC and different doses of RIP were illustrated in Fig. 2. Compared with the normal group (Fig. 2a), the hepatocytes in the model group (Fig. 2b) had edema and partial necrosis. A large number of vacuolar changes were observed in the

Table 5 Effects of different treatments on the activities of CAT (U/mg protein), SOD (U/mg protein), GSH-Px (U/mg protein) and levels of MDA (nmol/mg protein) and TAOC (U/mg protein) in the livers of aging mice

\begin{tabular}{llllll}
\hline Group & MDA & TAOC & CAT & SOD & GSH-Px \\
\hline Normal control & $1.43 \pm 0.10$ & $1.22 \pm 0.15$ & $36.18 \pm 0.30$ & $171.39 \pm 16.44$ & $399.67 \pm 16.92$ \\
Model control & $2.78 \pm 0.09^{\mathrm{d}}$ & $0.96 \pm 0.11^{\mathrm{c}}$ & $28.05 \pm 3.28^{\mathrm{d}}$ & $100.89 \pm 3.77^{\mathrm{d}}$ & $343.89 \pm 19.44^{\mathrm{a}}$ \\
Positive control & $1.34 \pm 0.09^{\mathrm{b}}$ & $2.08 \pm 0.33^{\mathrm{bd}}$ & $49.67 \pm 2.24^{\mathrm{bd}}$ & $116.71 \pm 8.18^{\mathrm{ad}}$ & $479.49 \pm 23.56^{\mathrm{bd}}$ \\
RIP $(25 \mathrm{mg} / \mathrm{kg})$ & $2.22 \pm 0.14^{\mathrm{ad}}$ & $1.09 \pm 0.14^{\mathrm{c}}$ & $35.51 \pm 1.34^{\mathrm{b}}$ & $107.36 \pm 10.86^{\mathrm{d}}$ & $345.65 \pm 12.35^{\mathrm{c}}$ \\
RIP $(50 \mathrm{mg} / \mathrm{kg})$ & $2.01 \pm 0.10^{\mathrm{ab}}$ & $1.59 \pm 0.17^{\mathrm{ac}}$ & $39.41 \pm 1.97^{\mathrm{bc}}$ & $124.62 \pm 11.53^{\mathrm{ad}}$ & $378.94 \pm 15.05^{\mathrm{a}}$ \\
RIP $(100 \mathrm{mg} / \mathrm{kg})$ & $1.80 \pm 0.10^{\mathrm{ac}}$ & $1.78 \pm 0.22^{\mathrm{bc}}$ & $42.57 \pm 2.19^{\mathrm{bd}}$ & $136.92 \pm 9.15^{\mathrm{bd}}$ & $414.85 \pm 19.95^{\mathrm{dc}}$ \\
\hline
\end{tabular}

Data were presented as means \pm S.D. $(n=10)$ and evaluated by one-way ANOVA followed by the Duncan's multiple-range tests

a $P<0.05$, compared with model group

${ }^{b} P<0.01$, compared with model group

c $P<0.05$, compared with normal group

${ }^{\mathrm{d}} P<0.01$, compared with normal group 
Table 6 Effects of different treatments on the activities of CAT (U/mg protein), SOD (U/mg protein), GSH-Px (U/mg protein) and levels of MDA (nmol/mg protein) and TAOC (U/mg protein) in the kidneys of aging mice

\begin{tabular}{llllll}
\hline Group & MDA & TAOC & CAT & SOD & GSH-Px \\
\hline Normal control & $1.46 \pm 0.24$ & $1.69 \pm 0.10$ & $32.77 \pm 2.44$ & $102.35 \pm 5.42$ & $248.16 \pm 8.14$ \\
Model control & $2.38 \pm 0.26^{\mathrm{d}}$ & $0.88 \pm 0.08^{\mathrm{d}}$ & $25.44 \pm 1.78^{\mathrm{d}}$ & $74.33 \pm 6.96^{\mathrm{d}}$ & $174.23 \pm 7.92^{\mathrm{d}}$ \\
Positive control & $1.17 \pm 0.28^{\mathrm{bc}}$ & $1.61 \pm 0.12^{\mathrm{b}}$ & $34.99 \pm 0.92^{\mathrm{b}}$ & $87.27 \pm 8.00^{\mathrm{ad}}$ & $259.39 \pm 10.37^{\mathrm{bc}}$ \\
RIP $(25 \mathrm{mg} / \mathrm{kg})$ & $1.84 \pm 0.38^{\mathrm{ac}}$ & $1.28 \pm 0.12^{\mathrm{ac}}$ & $26.36 \pm 1.72^{\mathrm{d}}$ & $76.00 \pm 9.04^{\mathrm{d}}$ & $186.41 \pm 8.45^{\mathrm{ad}}$ \\
RIP $(50 \mathrm{mg} / \mathrm{kg})$ & $1.67 \pm 0.29^{\mathrm{a}}$ & $1.42 \pm 0.16^{\mathrm{bc}}$ & $32.62 \pm 1.89^{\mathrm{a}}$ & $92.10 \pm 4.59^{\mathrm{bc}}$ & $212.57 \pm 6.82^{\mathrm{ac}}$ \\
RIP $(100 \mathrm{mg} / \mathrm{kg})$ & $1.30 \pm 0.35^{\mathrm{a}}$ & $1.81 \pm 0.28^{\mathrm{b}}$ & $43.92 \pm 0.87^{\mathrm{bd}}$ & $112.48 \pm 6.13^{\mathrm{bc}}$ & $236.78 \pm 9.15^{\mathrm{bc}}$ \\
\hline
\end{tabular}

Data were presented as means \pm S.D. $(n=10)$ and evaluated by one-way ANOVA followed by the Duncan's multiple-range tests

a $P<0.05$, compared with model group

${ }^{\mathrm{b}} P<0.01$, compared with model group

${ }^{c} P<0.05$, compared with normal group

${ }^{\mathrm{d}} P<0.01$, compared with normal group

liver tissues of the mice in the model group, indicating obvious looseness, swelling, focal necrosis, and inflammatory cell infiltration. However, there was significant improvement in the high-dose group (100 $\mathrm{mg} / \mathrm{kg} \mathrm{bw})$ and the medium-dose group $(50 \mathrm{mg} / \mathrm{kg}$ bw), but not in the low-dose group ( $25 \mathrm{mg} / \mathrm{kg} \mathrm{bw})$. The results of histopathological evaluation showed that RIP exhibited a hepatoprotective effect against D-galactose-induced liver injury.

\section{The effects of RIP on histology changes in kidneys}

The degree of renal injury of D-galactose was observed by pathological section. It could be seen from Fig. 3 that different concentrations of RIP have certain protective effects on renal damage caused by D-galactose. The mice in the model group had significant pathological changes in their kidneys with distal convoluted tubule expansion and vacuoles in epithelial cells (Fig. 3b). These alterations in the kidneys of aging mice were ameliorated almost to normal levels after treatments with high doses of RIP, shown in Fig. 3f. Hence, RIP could alleviated kidney damage induced by $\mathrm{D}$-galactose.

\section{The effect of the RIP on the activities of antioxidant enzymes in liver, kidney and brain in aging mice}

The effects of RIP on activities of various antioxidant enzymes in serum, livers and kidneys were presented in Tables 4, 5, 6 respectively. Compared with the normal control group, MDA concentration in serum and tissue of mice in model control group increased significantly $(P<0.05)$, but antioxidant enzymes (SOD, CAT, GSH-Px and TAOC) activity decreased significantly. Different doses of RIP $(25 \sim 100 \mathrm{mg} / \mathrm{kg})$ significantly $(P<0.05)$ inhibited the formation of MDA and increased the activities of antioxidant enzymes in serum, livers and kidneys. As shown in Table 7, RIP does not significantly protect the brain from oxidative damage $(P>0.05)$.

\section{Discussion}

Protein is another important biological active component in plants besides alkaloids, polysaccharides and saponins, which has attracted more and more attention in recent years. Some studies have found that plant proteins can directly remove free radicals and play an anti-oxidation role. At present, plant-derived antioxidant proteins have unique physiological functions and broad application

Table 7 Effects of different treatments on the activities of CAT (U/mg protein), SOD (U/mg protein), GSH-Px (U/mg protein) and levels of MDA ( $\mathrm{nmol} / \mathrm{mg}$ protein) and TAOC (U/mg protein) in the brains of aging mice

\begin{tabular}{llllll}
\hline Group & MDA & TAOC & CAT & SOD & GSH-Px \\
\hline Normal control & $1.07 \pm 0.07$ & $1.01 \pm 0.15$ & $32.07 \pm 2.02$ & $258.22 \pm 12.68$ & $319.32 \pm 8.94$ \\
Model control & $1.63 \pm 0.27^{\mathrm{d}}$ & $0.64 \pm 0.09^{\mathrm{d}}$ & $25.75 \pm 2.23^{\mathrm{d}}$ & $162.78 \pm 23.86^{\mathrm{d}}$ & $228.75 \pm 6.95^{\mathrm{d}}$ \\
Positive control & $0.89 \pm 0.08^{\mathrm{bc}}$ & $1.27 \pm 0.12^{\mathrm{bc}}$ & $49.67 \pm 2.24^{\mathrm{bd}}$ & $250.47 \pm 11.65^{\mathrm{b}}$ & $354.29 \pm 11.28^{\mathrm{bc}}$ \\
RIP $(25 \mathrm{mg} / \mathrm{kg})$ & $1.61 \pm 0.07$ & $0.66 \pm 0.04$ & $24.27 \pm 2.53$ & $164.91 \pm 17.81$ & $224.87 \pm 12.62$ \\
RIP $(50 \mathrm{mg} / \mathrm{kg})$ & $1.58 \pm 0.10$ & $0.67 \pm 0.08$ & $25.33 \pm 3.19$ & $165.98 \pm 15.02$ & $227.56 \pm 14.89$ \\
RIP $(100 \mathrm{mg} / \mathrm{kg})$ & $1.55 \pm 0.10$ & $0.71 \pm 0.20$ & $25.40 \pm 2.56$ & $165.47 \pm 11.65$ & $229.36 \pm 15.63$ \\
\hline
\end{tabular}

Data were presented as means \pm S.D. $(n=10)$ and evaluated by one-way ANOVA followed by the Duncan's multiple-range tests

a $P<0.05$, compared with model group

${ }^{b} P<0.01$, compared with model group

c $P<0.05$, compared with normal group

${ }^{\mathrm{d}} P<0.01$, compared with normal group 
prospects because of their superior antioxidant activity and high safety. The antioxidant activity of RIP was affected by different kinds of amino acids in different molecular weight peptide segments. According to our current research results, the molecular weight of RIP is mainly distributed in $17 \sim 26 \mathrm{kDa}$. RIP was rich in essential amino acids and could be used as a nutritional supplement. Antioxidant amino acids might control antioxidant potentials of protein and peptides. According to the literature antioxidant amino acids usually contain hydrophobic amino acids (valine, alanine, proline and leucine), aromatic amino acids (tyrosine, histidine, and phenylanine), and methionine [19]. The total content of antioxidant amino acids in RIP was $29.63 \mathrm{~g} / 100 \mathrm{~g}$. Antioxidant amino acids were implicated in the control of antioxidant potentials of proteins and peptides [20]. It could be inferred that the antioxidant amino acids play an important role in the antioxidant effect of RIP.

Modern medical research shows that immunity is a factor closely related to aging and immune function decline is one of the most important causes of aging [21]. The thymus and spleen are important immune organs, so the thymus and spleen indexes suggest activation, enhancement or strengthening of the immune status or immune function. The results indicated that RIP improved immunity and protected the liver and kidney from oxidative damage in aging mice.

The occurrence of many diseases is related to lipid peroxidation induced by free radicals. Free radicals can induce lipid peroxidation, and one of the most important ways to damage the body is to produce lipid peroxides. Normally, free radicals can maintain a balance below the damage threshold, which depends on the body's antioxidant system. Under the action of galactose oxidase, D-galactose generates acetaldehyde sugar and hydrogen peroxide, which increase the amount of reactive oxygen and hyperlipidemia, and generates superoxide anion free radicals, thus leading to the aging of the body [22]. MDA is a kind of harmful substance, which can cause the cross-linking polymerization of proteins, nucleic acids and other life macromolecules, and has cytotoxicity. The content of MDA often reflects the degree of lipid peroxidation in vivo, and indirectly reflects the degree of cell damage [23]. Medium and high doses of RIP could significantly reduce the content of MDA in serum and tissues of mice with oxidative damage $(P<$ 0.05). This may be due to the effect of RIP on stabilizing the cell membrane structure and inhibiting lipid peroxidation. SOD, GSH-Px, T-AOC and CAT are important antioxidant enzymes in the body, and their activity can comprehensively reflect the antioxidant capacity of the body. With the increase of age, the activity of antioxidant enzymes in human body decreases gradually, mainly because the genes encoding antioxidant enzymes and antioxidant enzymes themselves are damaged by free radical oxidation [24]. RIP could enhance the activity of SOD, GSH-Px, T-AOC and CAT in serum, liver and kidney of mice to enhance the ability of enzymatic system to resist free radical reaction, and reduce the oxidation of free radicals to unsaturated fatty acids, thus reducing the content of MDA to a certain extent. This study showed that RIP could eliminate the damage of free radicals in the body and has a good antioxidant effect in vivo.

\section{Conclusions}

The total content of essential amino acids in RIP met the requirements of $\mathrm{FAO} / \mathrm{WHO}$ for 2-5 years old infants. RIP was rich in antioxidant amino acids $(29.63 \mathrm{~g} /$ $100 \mathrm{~g}$ RIP) which may contribute to the antioxidant activities. Thus, RIP may be suitable for human consumption as a source of protein nutrition and antioxidants. This study firstly evaluated the antioxidant activity of RIP in a D-galactose induced aging mice model in vivo. These results revealed that RIP effectively alleviated the oxidative damage and could be explored as a potential source of protein nutrition for dietary supplement.

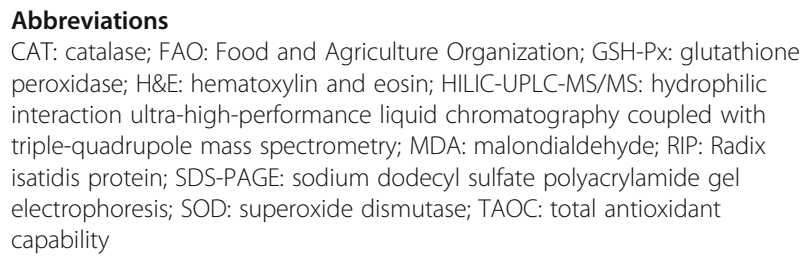

\section{Acknowledgments}

We are grateful to Dr. Derek Kennedy (Nanthan campus, Griffith University, Australia) for improving our paper.

\section{Authors' contributions}

$\mathrm{PX}, \mathrm{XL}$ and JAD conceived and designed the experiments; PX and $\mathrm{HZH}$ performed the experiments; JWC and JAD analyzed the data; $H Z H, X L$ and JAD contributed reagents/materials/analysis tools; PX wrote the paper. All the authors have read and approved the final manuscript.

\section{Funding}

The financial grants of this work have been supported by the National Natural Science Foundation of China (81703642), Key Project of Jiangsu Collaborative Innovation Center of Chinese Medicinal Resources

Industrialization (ZDXM-3-19), Top-notch Academic Programs Project of Jiangsu Higher Education Institutions (TAPP-PPZY2015A070), and Project Funded by the Priority Academic Program Development of Jiangsu Higher Education Institutions (PAPD). The Funding bodies play no role in the design of the study and collection, analysis, and interpretation of data and in writing the manuscript.

\section{Availability of data and materials}

The raw data generated and/or analyzed during the current study are available from the corresponding author on reasonable request.

Ethics approval and consent to participate

This study was approved by Animal Ethical Council of Nanjing University of Chinese Medicine. 


\section{Consent for publication}

Not applicable.

\section{Competing interests}

The authors declare that they have no competing interests.

Received: 5 June 2018 Accepted: 23 October 2019

Published online: 06 November 2019

\section{References}

1. Ho YL, Chang YS. Studies on the antinociceptive, anti-inflammatory and anti pyretic effects of Isatis indigotica root. Phytomedicine. 2002;9(5):419-24.

2. Chung YC, Tang FY, Liao JW, Chung CH, Jong TT, Chen SS, et al. Isatis indigotica induces hepatocellular cancer cell death via caspase-independent apoptosis-inducing factor translocation apoptotic pathway in vitro and in vivo. Integr Cancer Ther. 2011:10(2):201-14.

3. Zhou W, Zhang XY. Research Progress of Chinese herbal medicine Radix isatidis (Banlangen). Am J Chinese Med. 2013:41 (4):743-64.

4. Xiao P, Huang HZ, Chen JW, Li X. In vitro antioxidant and anti-inflammatory activities of Radix Isatidis extract and bioaccessibility of six bioactive compounds after simulated gastro-intestinal digestion. J Ethnopharmacol. 2014;157:55-61.

5. Du Z, Liu H, Zhang Z, Li P. Antioxidant and anti-inflammatory activities of Radix Isatidis polysaccharide in murine alveolar macrophages. Int J Biol Macromol. 2013:58:329-35.

6. Sheih IC, Wu TK, Fang TJ. Antioxidant properties of a new antioxidative peptide from algae protein waste hydrolysate in different oxidation systems. Bioresour Technol. 2009;100(13):3419-25.

7. Chen N, Yang HM, Sun Y, Niu J, Liu SY. Purification and identification of antioxidant peptides from walnut (Juglans regia L.) protein hydrolysates. Peptides. 2012:38(2):344-9.

8. Escudero E, Mora L, Fraser PD, Aristoy MC, Toldra F. Identification of novel antioxidant peptides generated in Spanish dry-cured ham. Food Chem. 2013;138(2-3):1282-8.

9. Delgado M, Tironi VA, Anon MC. Antioxidant activity of amaranth protein or their hydrolysates under simulated gastrointestinal digestion. LWT-FOOD SCIENCE AND TECHNOLOGY. 2011;44(8):1752-60

10. Chen $\mathrm{H}$, Cheng Y, Li X, Chen JW, Li J, Xue P, et al. Antioxidation and protection against $\mathrm{H}_{2} \mathrm{O} 2$ induced oxidative stress on normal human hepatocytes cell line (LO2) by extracts and three compounds from the root of Isatis Indigotica. J Med Plants Res. 2012;6(10):1886-90.

11. Hu XC, Jiang JR, Xu Y. The study of Radix Isatidis active protein acute toxicity [J]. Chinese J Nat. 2000;02:122-3.

12. Zhou J, Liu J, Lin D, Gao G, Wang H, Guo J, et al. Boiling-induced nanoparticles and their constitutive proteins from Isatis indigotica fort. Root decoction: purification and identification. J Tradit Complement Med. 2017; 7(2):178-87.

13. Meydani M. Dietary antioxidants modulation of aging and immuneendothelial cell interaction. Mech Ageing Dev. 1999;111(2-3):123-32.

14. Xiao P, Huang HZ, Chen YY, Chen JW, Li X, Shi HT. Nutritional evaluation, characterization and antioxidant activity of Radix Isatidis protein hydrolysates under simulated gastrointestinal digestion. J Food Nutr Res. 2014;11(2):831-8.

15. Prandi B, Bencivenni M, Faccini A, Tedeschi T, Dossena A, Marchelli R, et al. Composition of peptide mixtures derived from simulated gastrointestinal digestion of prolamins from different wheat varieties. J Cereal Sci. 2012; 56(2):223-31.

16. Pan YL, Li J, Li X, Chen JW, Bai GG. Determination of free amino acids in Isatidis Radix by HILIC-UPLC-MS/MS. B Kor Chem Soc. 2014;35(1):197-203.

17. Chavan UD, McKenzie DB, Shahidi F. Protein classification of beach pea (Lathyrus maritimus L.). Food Chem. 2001;75(2):145-53.

18. Energy and protein requirements. Report of a joint FAO/WHO/UNU Expert Consultation. World Health Organ Tech Rep Ser. 1985;724:1-206.

19. Xie NN, Wang C, Ao J, Li B. Non-gastrointestinal-hydrolysis enhances bioavailability and antioxidant efficacy of casein as compared with its in vitro gastrointestinal digest. Food Res Int. 2013;51(1):114-22.

20. Fang XB, Xie NN, Chen X, Yu H, Chen J. Optimization of antioxidant hydrolysate production from flying squid muscle protein using response surface methodology. Food Bioprod Process. 2012;90(C4):676-82.
21. Ke CL, Qiao DL, Gan D, Sun Y, Ye H, Zeng XX. Antioxidant acitivity in vitro and in vivo of the capsule polysaccharides from Streptococcus egui subsp zooepidemicus. Carbohyd Polym. 2009;75(4):677-82.

22. Qiao DL, Ke CL, Hu B, Luo JG, Ye H, Sun Y, et al. Antioxidant activities of polysaccharides from Hyriopsis cumingii. Carbohyd Polym. 2009;78(2):199-204.

23. Lei L, Chen Y, Ou L, Xu Y, Yu X. Aqueous root extract of Asparagus cochinchinensis (Lour.) Merr. Has antioxidant activity in D-galactose-induced aging mice. BMC Complement Altern Med. 2017;17(1):469.

24. Ames BN, Shigenaga MK, Hagen TM. Oxidants, antioxidants, and the degenerative diseases of aging. Proc Natl Acad Sci U S A. 1993;90(17):7915-22.

\section{Publisher's Note}

Springer Nature remains neutral with regard to jurisdictional claims in published maps and institutional affiliations.
Ready to submit your research? Choose BMC and benefit from:

- fast, convenient online submission

- thorough peer review by experienced researchers in your field

- rapid publication on acceptance

- support for research data, including large and complex data types

- gold Open Access which fosters wider collaboration and increased citations

- maximum visibility for your research: over $100 \mathrm{M}$ website views per year

At $\mathrm{BMC}$, research is always in progress.

Learn more biomedcentral.com/submissions 